\title{
The Gorbachev Anti-Alcohol Campaign and Russia's Mortality Crisis
}

\author{
BY Jay Bhattacharya, Christina Gathmann, and Grant Miller* \\ Online Appendices
}

\section{Appendix I: Data}

This appendix describes the sources used to construct our new oblast-year panel data set spanning 1970-2000 that includes mortality rates, official alcohol sales, alcohol prices, alcohol production, and socio-economic and demographic characteristics. We use the term "oblast" throughout, but geographic areas also include several krais (Altaiskii, Krasnodarskiy, Krasnoyarskii, Khabarovskii, Primorskii, Stavropolski) and autonomous republics (Altai, Bashkortostan, Buryatiya, Chuvash, Dagastan, Kabardino-Balkarskaya, Kalmykaya, Karachaevo-Cherkesskaya, Karelia, Khakasiya, Komi, Marii-El, Mordovaya, North OsetiyaAlaniya, Sakha, Taatarstan, Tuva, Udmurtskaya). We exclude autonomous okrugs (Aginsky, Eventsky, Chukotsky, Khanty-Mansiisk, Komi-Permiatsky, Koryaksky Nenets, Nenetsky, Taimyrskii (or Dolgano-Nentsky), Usy-Ordynsky, Yamalo-Nenetsky) from the analysis because we do not have information about them for several key years. Overall, our analyses therefore generally include 77 oblasts (including krais and republics).

From the 1960s until 1986, statistics on deaths, alcohol production/consumption, and crime were collected but not made publicly available for political purposes. Under Glasnost and Mikhail Gorbachev's leadership, however, the Central Statistical Office of the Soviet Union (Goskomstat) resumed publication of oblast-level mortality statistics in annual demographic yearbooks in 1986 (publication of official alcohol sales data and crime statistics resumed shortly thereafter - in 1987 and 1988, respectively). Since the 1980s, an estimated 94\% of all deaths in Russia have been medically certified (with the remainder certified by trained paramedics called feldshers) (Shkolnikov et al. 1996). Oblast governments then use these death records to construct oblast-level mortality statistics by age, sex, and cause. In principle, these oblast-year statistics are available from Goskomstat (and its successor Rosstat). Obtaining these records is not easy in practice, so we also conducted a comprehensive search of all Russian and English language publications with statistics on mortality, alcohol, and crime in constructing our data set.

\section{A. Vital Statistics}

Our primary dependent variable is the crude death rate (CDR), which is defined as the number of deaths per 1,000 people. The CDR is calculated as the number of deaths from all causes in a calendar year divided by the mid-year de facto population (the official inter-censual population estimate) and is available for years 1970, 1978, 1980, 1985, 1986, and 1988-2000 (Goskomstat SSSR 1987; New World Demographics 1992; Goskomstat Rossii 1992; 1993a; 1995; 1996b-2005b).

We also study death rates (per 100,000 population) by several categories of causes. In the Soviet Union, cause-specific deaths were reported using a Soviet classification system containing 175 categories. These were later reclassified according to the World Health 
Organization's International Classification of Diseases (ICD) (see below). Given the focus of our study, an important cause of death is alcohol poisoning (a marker for a broader set of alcohol-related deaths). The Soviet Union and Russian Federation require that sudden, unexpected deaths be investigated (by autopsy). Cases of alcohol poisoning are identified when blood alcohol concentrations exceed $250 \mathrm{mg} / \mathrm{dl}$ and in the absence of other apparent causes. Alcohol poisoning deaths are reported separately for men and women and are available for years 1978/9 and 1988-2000. These data were graciously provided by Vladimir Shkolnikov. To convert alcohol poisoning deaths (which are reported by age group for years 1989-2000) into overall death rates (per 100,000), we use the 1998 European Standard Population. Alcohol poisoning death rates are then the weighted average of the age-specific rates (using standardized population shares as weights).

In addition to alcohol poisonings, we study data on deaths by other major causes: neoplasms/cancers (group 2, codes 140-239), circulatory diseases including cardiovascular diseases (group 7, codes 390-459), acute respiratory infections (group 8, codes 460-519), diseases of the digestive system (group 9, codes 520-579) and accidental/violent deaths (accidents, other poisonings, homicide, and suicide (group 17, codes 800-999). About half of deaths in the last category are thought to be alcohol-related (Nemtsov 1998; 2000). These data are available for 1978/8, 1988/9 and annually since 1990 (Goskomstat Rossii 1993b; Goskomstat Rossii 1996b-2005b; Vallin et al. 2005).

Evaluations of Russia's mortality statistics generally conclude that they are acceptable in quality with relatively little under-reporting. Exceptions are Tuva and regions in the North Caucasus (Dagastan Republic, Ingushitya Republic, Chechen Republic, Kabardino-Balkarskaya Republic, Karachaevo-Cherkesskaya Republic, North Osetiya-Alaniya Republic, Krasnodarskiy Krai, and Stavropolski Krai) where studies of infant mortality under-reporting suggest rates as high as $25 \%$ during the 1980s (Blum and Monnier 1989). The cause of death statistics appear somewhat less reliable as many alcohol related deaths seem to be classified as cardiovascular disease or cause unknown (Andreev 1999, Gavrilova et. al. 2005, Zaridze et al. 2009).

Between 1969 and 1991, the Soviet cause-of-death classification system was changed three times (in 1970, 1981 and 1988). The Soviet system from 1965 to 1970 was similar to WHO ICD-8 codes, and the revisions in 1981 and 1988 closely resembled WHO ICD-9 codes (Goskomstat created a key matching the two) (Shkolnikov et al. 1996). The analyses of Vallin et al. (1996) suggest that the changes in 1970 and 1981 did not influence the registration of deaths from major causes (at least at ages up to age 65) (Vallin et al. 1996). The 1988 revision simply merged the previous classification's 'employment-related' and 'non-employment-related' alcohol poisoning subgroups into a single category. A comparison of data from Russia and the three Baltic countries (Estonia, Latvia, and Lithuania which shifted before 1999) shows no discontinuity, suggesting that data before and after the coding change are roughly comparable (Mesle et al. 1996).

\section{B. Population Measures}

Population estimates used to convert deaths into death rates are based on the Soviet censuses of 1970, 1979, and 1989 Soviet censuses and the 2002 census of the Russian 
Federation. These censuses were conducted on January15, 1970; January17, 1979 and 1989; and between October 9 and 16, 2002. Using census population counts, Goskomstat produced official population estimates for January 1 of each census year. For inter-census years, oblast statistical offices estimated their populations using information on births and deaths as well. Population estimates were also adjusted using data on internal migration collected by the Ministry of the Interior. Mid-year de facto populations used as denominators for constructing rates are calculated as arithmetic means of population estimates at the beginning of a given year and the subsequent year (Goskomstat SSSR 1990; New World Demographics 1992; Goskomstat Rossii 1993c; Goskomstat Rossii 1995a-2005a).

\section{Alcohol Sales}

As a monopolist, the government of the Soviet Union decided official alcohol production, pricing, foreign trade, and domestic distribution. Goskomstat collected statistics on alcohol sales from reports of government retail trade networks across the country (but do not alcohol sold on military bases). After Russia's political and economic transition, Rosstat continued collecting data in the same way, although data after 1992 do not include legal private trade and restaurant sales. More importantly, official sales statistics also do not include illegal home production of alcohol (samogon).

Data on official sales are reported in billions of rubles and in volume of pure alcohol for years 1970, 1980, 1985 and 1989. In addition, official sales data are reported in liters of pure alcohol per person for 1970, 1980, 1984, 1985 and 1989-1992. We also have information on sales of specific types of alcoholic beverages (vodka, wine, beer, champagne, and cognac). The numbers for individual beverages sales are reported in liters per person and are available for years 1970, 1980-1992, and 1997-2000. Sales data for cognac and champagne were available since 1999 only. We converted the sales data for specific types of beverages into total sales of pure alcohol using the following assumptions about alcohol concentrations for each type of beverage (from Andrienko and Nemtsov 2006): Russian vodka 40\%; wine 14.4\%; cognac 18\%; champagne 22.8\%; beer 2.85\% (before 1995), 3.37\% (between 1995 and 1999), and 3.85\% (after 2000). To summarize, we calculate alcohol consumption per capita in liters of pure alcohol from sales of different types of alcoholic beverages using the following formula:

$$
\begin{gathered}
\text { Liters of Pure alcohol }=0.144 * \text { wine }+0.4 * \text { vodka }+0.228 * \text { champagne }+0.18 * \text { cognac }+ \\
0.28 \text { beer }^{*} 1(1970-1994)+0.337 * \text { beer }^{*} 1(1995-1999)+0.389 * \text { beer }^{*} 1(2000-2005) \text {. }
\end{gathered}
$$

We thus generate a panel of oblast-level total alcohol sales data from 1970 to 2000 (with data missing between 1971 and 1979). The data prior to 1997 (when both official sales and sales of specific beverages types are reported) show that our calculations using beverage-specific data closely matches the Goskomstat official data on pure alcohol sales.

\section{Alcohol production and prices}

The government controlled alcohol production and prices which were set by the administration and not determined by market forces during the Soviet regime. The most 
comprehensive information on production is available for vodka which is also the most popular beverage in Russia. Data on vodka production are reported in 1,000 liters for 1970, 1979, 1980, 1985 and 1990-2000 (Goskomstat Rossii 1993a; 1998g; 2000g; 2002g; 1999h-2004h; TsCU SSSR 1971; 1980). In addition, we have information on production of pure alcohol in rubles per person for 1989-1992, 1994, 1995, 1997 and 1999-2000 (Goskomstat SSSR 1989b; Goskomstat Rossii 1993a; 1995a; 1997f; 1998f; 1999h-2004h). We use the oblast-specific share of vodka production in total alcohol production in 1990 to construct vodka production in 1989 (from information on pure alcohol production).

Alcohol prices are available at the oblast level only following Russia's political and economic transition. Specifically, we have annual information about the price of a liter of domestic vodka at the end of year beginning in 1992 (Goskomstat Rossii 1996c; 1996d; 1997e; 1998e; 2002c; 2006c). For earlier years, we calculate alcohol prices using information on official alcohol sales and production. For alcohol sales, we have data in liters per person and rubles for years $1970,1980,1985$, and 1989. In addition, we have data on alcohol production both in 1,000 liters and rubles per person for 1999-2000. We then calculate the price of a liter of pure alcohol between 1970 and 1989 by dividing total sales in rubles by the total quantity sold (or produced). Similarly, we calculate the price of pure alcohol after 1999 by multiplying total alcohol production in rubles per person by the oblast population and then dividing by total alcohol produced (in liters).

\section{E. Other Covariates}

To control for other factors influencing mortality in Russia, we assembled oblast-year data on employment, income, health care infrastructure, fertility, and migration. Employment is measured as the number of people employed per 1000 population and is available for 1985 and all years beginning in 1990 (Goskomstat Rossii 1997f, 2002j, 2006j). We also use data on the share of employment in private manufacturing, which is available for all years beginning in 1992 (Brown, Earle and Gehlbach 200, Earle and Gehlbach 2010). Income is measured as average income per month in real Rubles and is available for years 1970, 1980, 1985, 1989-1992, and all years beginning in 1994 (Goskomstat Rossii 1992, 1993a, 1996a-2005a, Treml and Alexeev 1993). Our health care infrastructure and workforce measures are the number of hospital beds per capita and the number of doctors per capita; these variables are available for years 1970 , 1975, 1980 and all years beginning in 1985 (Goskomstat Rossii 1994, 1997f-2001f, 2002i-2005i, Goskomstat SSSR 1990b). Crude birth rate data (defined as the number of births per 1,000 population) is available for years 1970, 1980, 1985-1986, and all years beginning in 1988 (Goskomstat SSSR 1987, Goskomstat Rossii 1992, 1993a, 1995, 1996b-2005b, New World Demographics 1992). Finally, data on immigration and emigration flows are available for all years beginning in 1989 (Andrienko and Guriev 2004, Goskomstat SSSR 1990a, Goskomstat Rossii 1993b, 1995, 2002i-2005i).

\section{Additional Data Source References:}

Gavrilova Natalia S., Victoria G. Semyonova, Galina N. Evdokushkina, Alla E. Ivanova, and Leonid A. Gavrilov. 2005. "Problems with Mortality Data in Russia." Paper presented at the Population Association of America Annual Meeting, Philadelphia, PA. 


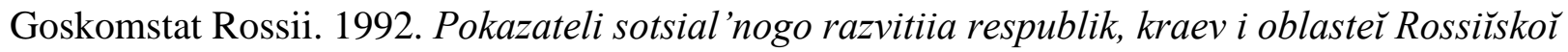
Federatsii. Moscow: Goskomstat.

Goskomstat Rossii. 1993a. Pokazateli sotsial'nogo razvitiia respublik, kraev i oblasteŭ Rossiǔskou Federatsii. Moscow: Goskomstat.

Goskomstat Rossii. 1993b. Demograficheskii Ezhegodnik Rossii. Moscow: Goskomstat.

Goskomstat Rossii. 1993c. Rossiǔskaia Federatsiia v 1992 godu. Moskow: Goskomstat.

Goskomstat Rossii. 1994. Rossiǔskiu Statisticheskiu Ezhegodnik: statisticheskiŭ sbornik. Moscow: Goskomstat.

Goskomstat Rossii. 1995. Demograficheskii Ezhegodnik Rossii. Moscow: Goskomstat.

Goskomstat Rossii. 1995a-2005a. Rossiiskii statisticheskii ezhegodnik, Moscow: Goskomstat.

Goskomstat Rossii. 1996b-2005b. Demograficheskii Ezhegodnik Rossii. Moscow: Goskomstat.

Goskomstat Rossii. 1996c, 2002c, 2006c. Tseny v Rossii : statisticheskiŭ sbornik, Moscow:

Goskomstat.

Goskomstat Rossii. 1996d. Srochnoe Soobshchenie ob izmenenii tsen na prodovolstvennie tovari posostoyaniyu na 30 dek 1996, Moscow: Goskomstat.

Goskomstat Rossii. 1997e-1998e. Srednie ts eny na prodovolstvennie tovary v dekabrya. Moscow: Goskomstat.

Goskomstat Rossii. 1997f-2001f. Regiony Rossii, Moscow: Goskomstat.

Goskomstat Rossii. 1998g, 2000g, 2002g. Promyshlennost' Rossii: statisticheskii sbornik. Moscow: Goskomstat.

Goskomstat Rossii. 1999h-2004h. Proizvodstvo i oborot etilovogo spirta i alkogol'noi produktsii v Rossiiskoi Federatsii. Moscow: Goskomstat.

Goskomstat Rossii. 2002i-2005i. Regiony Rosii. Sotsial'no-ekonomicheskie pokazateli, Moscow: Goskomstat.

Goskomstat Rossii. 2002j, 2006j. Ekonomicheskaia aktivnost' naseleniia Rossii. Moscow: Goskomstat.

Goskomstat SSSR. 1987. Naselenie SSSR, Moskow: Finansy i statistika.

Goskomstat SSSR. 1990a. Demograficheskii Ezhegodnik SSSR. Moscow: Goskomstat. 
Goskomstat SSSR. 1989b-1990b. Narodnoe khoziaistvo SSSR: statisticheskii ezhegodnik, Moscow: Goskomstat.

TsCU SSSR. 1971. “Otchet o proizvodstve produktsii pishchevoi promyshlennosti po formam podchineniya, posoyuznym respublikam, oblastyam, krayam, ASSR za 1970 god (itogi raztabotki godovykh otchetov promyshlennykh predpritatii), Tom I.” Moscow.

TsCU SSSR. 1980. "Svodnyi otchet no itogam razrabotki godovykh otchetov promyshlennostikh predpriyatiyakh vyrazhenii po SSSR, ministerstvam, formam podchineniya, soyuznym respublikam, ekonomicheskim rayonam, oblastyam, krayam, ASSR za 1979 god.” Moscow. 


\section{Appendix II: Estimation of Total Alcohol Consumption (Official Alcohol Sales and Samogon Production)}

Official alcohol sales data measure sales of state-produced alcoholic beverages. However, anecdotal evidence suggests that illegal production of alcoholic beverages - especially samogon - increased during the Gorbachev Anti-Alcohol campaign. Because comprehensive oblast-year estimates of illegal alcohol production are not available, we extended the work of Nemtsov (2000) to estimate illegal alcohol production and consumption for the 1980s and early 1990s.

Nemtsov $(1998,2000)$ developed two indirect methods for estimating illegal alcohol consumption. First, Nemtsov (1998) exploits the fact that sugar is the main ingredient required for samogon production. For Moscow prior to 1986 (when the Soviet Union began to ration sugar), he used sugar sales data to estimate excess sugar sales by subtracting standard dietary requirements of sugar from total sugar sales. ${ }^{1}$ Excess sugar sales are then converted into samogon production estimates with information about the sugar concentration of samogon.

To estimate samogon production for years after 1986, Nemtsov (2000) used forensic records to develop a second indirect technique. Both the Soviet Union and the Russian Federation require each oblast's forensic bureau to perform autopsies for all violent and accidental deaths as well as for deaths with unclear causes. All autopsies report blood alcohol content, effectively providing a non-random sample of Russians with measures of alcohol concentration in the blood. Nemtsov (2000) calculates the ratio of autopsies with positive blood alcohol content (excluding alcohol poisoning deaths) to the number of autopsies with no blood alcohol content and parametrically relates this ratio to total alcohol consumption. He then uses this estimated parametric relationship to predict total (including illegal) alcohol consumption for 25 oblasts between 1980 and 1992, allowing him to recover implied samogon consumption (Nemtsov 2000). ${ }^{2}$ Autopsy-based estimates closely match sugar-based estimates for Moscow between 1983 and 1986 and outperform other methodologies (based on hospital admissions for alcohol-induced psychosis, cirrhosis deaths, and pancreatitis deaths, for example) (McKee 1999, Nemtsov 2000, Balan-Cohen 2007).

To generate oblast-year estimates of total alcohol consumption for key years in our data set, we use statistical relationships between official alcohol sales and estimated samogon consumption reported in Nemtsov (2000). Specifically, Nemtsov (2000) uses data from 25 oblasts in 1990 to regress samogon consumption on official alcohol sales, estimating the following relationship: samogon $=12.38-1.02 \times$ official sales. He also reports the correlation coefficient between official sales (OS) and samogon/illegal alcohol (IA) for years 1983, 1985 and 1990. Because the regression slope is equal to $\operatorname{Cov}(\mathrm{IA}, \mathrm{OS}) /(\operatorname{Var}(\mathrm{OS}))$ and the correlation coefficient $r=\operatorname{Cov}(\mathrm{IA}, \mathrm{OS}) /\left(\operatorname{Var}(\mathrm{IA})^{1 / 2} \times\left(\operatorname{Var}(\mathrm{OS})^{1 / 2}\right)\right.$, we can use the observed variance of

\footnotetext{
${ }^{1}$ Nemtsov (1998) uses the minimum amount of sugar sold (per person and month) in the state retail network during the period 1983 to 1986. The figure he uses $-24.3 \mathrm{~kg}$ of sugar (recorded for September of 1985) - is close to the average sugar consumption ( $24 \mathrm{~kg}$ ) in the Soviet Union as reported by the Institute of Nutrition of the Soviet Union in the Academy of Medical Sciences.

${ }^{2}$ These oblasts were Altai krai, Amur, Bashkiria, Ekaterinburg, Ivanova, Khabarovsk, Kaluga, Karelia, Kemerov, Kursk, Leningrad, Moscow city, Moscow oblast, Murmansk, Novgorod, Novosibirsk, Omsk, Orel, Rostov, Samara, Saratov, Sakhalin, St. Petersburg city, Yaroslav.
} 
official sales in 1990 to calculate the implied variance of samogon production in 1990. Assuming the variance of samogon production to remain constant over time, we then use the observed variance of official sales in 1983 and 1985 to calculate implied regression coefficients for years 1983 and 1985. We assign the slope in 1983 to pre-campaign years 1980-1984, the 1985 slope to campaign years 1985-1989, and the 1990 slope to post-campaign years 1990-1992.

We then calculate year-specific regression constants. To do so, we subtract observed annual national-level official alcohol sales from annual national-level total alcohol consumption reported by Nemtsov (2000), yielding annual national-level samogon consumption. With observed official alcohol sales and annual samogon consumption, we are then able to calculate implied year-specific regression constants.

Finally, we use these year-specific regression constants and slopes together with our oblast-year data on official alcohol sales to predict oblast-year samogon consumption. We then calculate total alcohol consumption as the sum of official sales and samogon consumption for years 1980-1992. To validate these predictions, we calculate mean total consumption for the same 25 oblasts studied in Nemtsov (2000), and we then compare annual means with those provided by Nemtsov (2000) for Russia's six regions (North and Northwest Region, Central Region, Northern Caucasus Region, Urals and Volga Region, Western Siberia Region, and Russian Far East Region). Appendix Table 4 shows that our calculations generally match these published figures. 


\section{Appendix III: Estimation and Simulation of the Temporal Relationship between Alcohol Consumption and Mortality in the Framingham Heart Study}

Many consequences of alcohol consumption occur over time. Specific examples include cirrhosis, hypertension, heart attacks, and strokes. There are suggestive reports that moderate alcohol consumption may increase longevity as well. However, given the magnitude of the decline in alcohol consumption under the Gorbachev Anti Alcohol Campaign, we would expect a reduction in mortality on balance. Similarly, we hypothesize that the relaxation of constraints to drinking at the end of the campaign increased mortality. The precise temporal relationship between contemporaneous alcohol consumption and subsequent mortality is unclear, however.

The objective of this appendix is to examine this temporal relationship with data from the Framingham Heart Study, a large longitudinal study uniquely suited for this purpose.

\section{A. The Framingham Heart Study}

Spanning 1948 to the present, the Framingham Heart Study has collected unusually detailed high-frequency cohort health data from three generations of individuals. At its inception, the study enrolled 5,209 randomly selected subjects from the population of Framingham, Massachusetts. Sampling children of the original participants, it then added an additional cohort of 5,124 individuals (and their spouses) in 1971 and a third generation of grandchildren (and their spouses) in 2002. Our analyses use individuals from the first cohort observed during years 1948-2000.

Investigators visit each member of all three cohorts every two years to administer a detailed questionnaire and medical examination. The study follows every participant until death, using death certificates to verify dates of death. Beginning with the seventh wave (which was conducted between 1960 and 1964), the study began collecting information about alcohol consumption. Specifically, the questionnaires ask respondents how many cocktails, glasses of beer, and glasses of wine (with a standard drink size specified) they consumed during the past month.

Using responses to these questions, we computed total alcohol consumption (grams per day) by multiplying the number of each type of drink consumed with its average alcohol content (and summing across the three products). Following the Framingham investigators, we define a standard drink to be 13.7 grams ( 0.018 liters) of pure alcohol. This amount of pure alcohol is found in 12-ounces ( 0.36 liters) of beer, 5 -ounces ( 0.15 liters) of wine, or 1.5 -ounces ( 0.04 liters) of 80-proof liquor such as gin, rum, vodka, or whiskey. We adjust for changes during the late 1960 s in the alcohol content of liquor (from 100\% to 80\% proof), the type of wine consumed (from fortified to table wine), and changes in average serving sizes in calculating total ethanol consumption. Between waves, we impute alcohol consumption at the level reported in the preceding wave.

The Framingham Heart Study provides an excellent source of information about alcohol consumption and mortality and is distinguished from other longitudinal data sets by its longevity 
and data quality. Hence, the Framingham Heart Study is well suited for estimating the temporal relationship between alcohol consumption and subsequent mortality.

\section{B. Estimation}

Our analysis proceeds as follows. Let $i=1 \ldots N$ denote each of the $N$ distinct individual in the study, let $k=1 \ldots K$ represent the wave in which the individual is interviewed. Individual $i$ is surveyed first at $a g e_{i 0}$ years old, and then at $a g e_{i 1} \ldots a g e_{i K}$ assuming that the individual survives to those ages. While interview waves were generally separated by two years, there was considerable variation in exact interview dates, and the survey was fielded every single calendar year after the start of the study. The Framingham sample cohort at wave 1 consists entirely of adults over the age of 28 .

Let $t_{i k}$ be the time elapsed between initial entry into the study and wave $k$. We normalize $t_{i 1}=0$ for each individual. Let dead $_{i}$ be the date (measured relative to $t_{1}$ ) that individual $i$ dies if he/she dies during the observation period, and let $\operatorname{dead}_{i}=\infty$ if the individual does not die during the observation period. So an individual will not be observed in wave $k$ if $t_{i k}>\operatorname{dead}_{i}$.

Let alc $_{i t}=\left\{\right.$ none $_{i t}$, light $_{i t}$, moderate $_{i t}$, heavy $\left._{i t}\right\}$ represent a vector of mutually exclusive and collectively exhaustive dummy 1rvariables indicating computed alcohol consumption category. We assign these dummies based on the amount of alcohol that individual $i$ reports drinking at time $t$ over the previous four weeks. We assign $n o n e_{i t}=1$ to individuals reporting no alcohol consumption over the past month, light ${ }_{i t}=1$ to individuals in the $0-25$ th percentiles of the alcohol consumption distribution (measured in grams of alcohol conditional on positive consumption), moderate it $_{2}=1$ to individuals in the $0-25$ th percentiles of the alcohol consumption distribution (measured in grams of alcohol conditional on positive consumption), and heavy $_{i t}=1$ to people above the 75 th percentile. In addition to alcohol consumption, we observe education $\left(e d u c_{i t}\right)$, which we divide into six mutually exclusive groups: 8th grade or less, some high school, high school graduate, some college, college graduate, and post-graduate. We also observe the sex of the respondent, coded as a dummy variable, male . $_{i}$.

Appendix Table 5 shows means and standard deviations of our key variables in waves 1 , 7 (the first wave asking alcohol consumption questions), 17, and 23. In the initial wave, there were 5,209 individuals in the cohort. As the sample ages, the number people in the sample decreases, due mainly to deaths. The proportion of females increases at successive ages because males have higher mortality rates at these ages. The proportion of the population that never attended high school decreases substantially over time because those with lower educational attainment have higher mortality hazards. In wave 7, 59\% of the population reported some alcohol consumption during the preceding month; $17 \%$ reported heavy drinking (that is heavy $_{i t}=1$ ). By wave 23 , the proportion of the cohort reporting some alcohol consumption falls to $39 \%$, and the share of heavy drinkers drops to $7 \%$. This is due to both differential mortality (as we will show) and less drinking with age. 
We first estimate a Cox proportional hazards model of the determinants (including alcohol consumption) of time to death from entry into the study. Let $\lambda_{i}(t)$ be the hazard rate of mortality for individual $i$ at time $t$. We model the mortality hazard as follows:

$$
\lambda_{i}(t)=\lambda_{0}(t) \exp \left(\beta_{1} a g e_{i t}+\beta_{2} e d u c_{i t}+\beta_{3} \text { male }_{i}+\beta_{4} a l c_{i t}\right)
$$

Here, $\lambda_{0}(t)$ is the baseline hazard rate. Appendix Table 6 shows the coefficient estimates (and robust standard errors) from the Cox proportional hazards regression. The results are intuitive. Males face a substantially higher mortality hazard than females, with a hazard ratio greater than 1.5; each year of age increases the hazard rate by about 8 percent. Those with education beyond high school have lower mortality hazards. Finally, heavy drinking increases the mortality hazard by about 11 percent relative to complete abstention. Mild or moderate drinking is associated with a lower but statistically insignificant mortality hazard.

\section{Simulation Analysis}

We next use estimates from the Cox model above to conduct simulation analyses. Specifically, we analyze temporal patterns of mortality rates for three different counterfactual scenarios. Scenario 1: we study the evolution of mortality rates over time following a hypothetical change from heavy drinking to abstention in the entire population. Scenario 2: we model an event analogous to the Gorbachev Anti-Alcohol Campaign in which heavy drinkers become light drinkers and moderate and light drinkers abstain from drinking for five years. At the end of the five-year "campaign" period, all individuals return to their previous alcohol consumption path. Scenario 3: we repeat scenario 2 but also include a temporary two-year increase in alcohol consumption (to levels above the path prior to the campaign) at the end of the "campaign." During these two years, previously heavy drinkers return to heavy drinking, previously moderate drinkers become heavy drinkers, previously light drinkers become moderate drinkers, and previous abstainers become light drinkers.

Formally, let $\widehat{a l c}_{i t}^{j}$ be the $j^{\text {th }}$ counterfactual path of alcohol consumption followed by individual $i$. Using our estimates and equation (1), we calculate the mortality hazard path predicted by the counterfactual alcohol consumption path:

$$
\hat{\lambda}_{i}^{j}(t)=\hat{\lambda}_{0}(t) \exp \left(\hat{\beta}_{1} a g e_{i t}+\hat{\beta}_{2} e d u c_{i t}+\hat{\beta}_{3} \text { male }+\hat{\beta}_{4} \widehat{a l c}_{i t}^{j}\right)
$$

$\hat{\lambda}_{i}^{j}(t)$ is the predicted mortality hazard path for the $j^{t h}$ counterfactual alcohol consumption path, $\hat{\lambda}_{0}(t)$ is the observed baseline hazard function, and $\hat{\beta}_{1} \ldots \hat{\beta}_{4}$ are the Cox regression coefficient estimates.

To simulate the three scenarios that we describe above, we need predictions for four counter-factual paths. We need four counter-factual paths for three scenarios because Scenario 1 compares two distinct counter-factual paths, while Scenarios 2 and 3 use one counter-factual path each and compare against the actually observed mortality path. For $j=1$, we set $\widehat{a l c}_{i t}^{1}$ such 
that $\widehat{n o n e}{ }_{i t}^{1}=1 \forall i, t .^{3}$ For $j=2$, we set $\widehat{a l c}_{i t}^{2}$ such that $\widehat{h e a v} y_{i t}^{2}=1=1 \forall i, t$. For $j=3$ and $j=4$, we set $\widehat{a l c}_{i t}^{3}$ and $\widehat{a l c}_{i t}^{4}$ according to Appendix Table 7: formula is:

The $j^{\text {th }}$ counterfactual survivor function for individual $i$ implied by this hazard rate

$$
S_{i}^{j}(t)=\exp \left(-\int_{0}^{t} \hat{\lambda}_{i}^{j}(u) d u\right)
$$

We calculate a discrete version of (3) for each individual in the population and for each counterfactual path.

For our simulations, we draw $k=1 \ldots K$ independent uniform random numbers, $z_{i k} \sim U[0,1]$, for each individual in the population. $k$ counts over the number of iterations in our simulation, and we set $K=1,000$. For a given iteration, we calculate the time of death in the simulation for each individual as follows:

$$
\operatorname{dead}_{i k}^{j}=\inf \left\{t \mid S_{i}^{j}(t) \leq z_{i k}\right\}
$$

It should be clear that $\lim _{\epsilon \rightarrow 0} P\left(t<\right.$ dead $\left._{i k}^{j}<t+\epsilon\right)=S_{i}^{j}(t) \forall k$.

Using draws of time to death, we calculate the number of people who die in each year, $d_{k}^{j}(t)$, as well as the size of the cohort alive, $p o p_{k}^{j}(t)$ :

$$
\begin{gathered}
d_{k}^{j}(t)=\sum_{i=1}^{N} 1\left(t<\text { dead }_{i k}^{j}<t+1\right) \\
\operatorname{pop}_{k}^{j}(t)=\sum_{i=1}^{N} 1\left(\text { dead }_{i k}^{j}>t\right)
\end{gathered}
$$

Here, 1(.) is the indicator function. The death rate in year $t$ is:

$$
\operatorname{rate}_{k}^{j}(t)=\frac{d_{k}^{j}(t)}{\operatorname{pop}_{k}^{j}(t)}
$$

From our four counterfactual paths, we examine the effect on the time path of the mortality for each of our three thought experiments. We calculate the following quantities:

$$
\operatorname{effect}_{1}(t)=\underset{k}{\operatorname{median}}\left\{\operatorname{rate}_{k}^{1}(t)-\operatorname{rate}_{k}^{2}(t)\right\}
$$

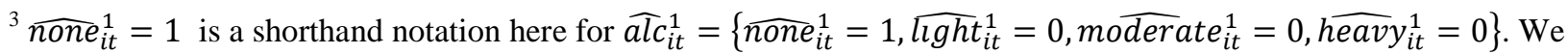
use similar shorthand throughout the remainder of this appendix.
} 


$$
\begin{aligned}
& \operatorname{effect}_{2}(t)=\underset{k}{\operatorname{median}}\left\{\text { rate }_{k}^{3}(t)-\text { rate }_{k}(t)\right\} \\
& \operatorname{effect}_{3}(t)=\underset{k}{\operatorname{median}}\left\{\text { rate }_{k}^{4}(t)-\text { rate }_{k}(t)\right\}
\end{aligned}
$$

\section{Results}

Appendix Figures 3-5 plot effect ${ }_{1}(t) \ldots$ effect $_{3}(t)$. Appendix Figure 3 shows the mortality rate difference over time for Scenario 1 (which compares a counterfactual scenario in which everyone is a heavy drinker against one in which everyone is an abstainer). In the Framingham study cohort, the move from heavy drinking to abstinence would have lowered mortality rate for a seventeen-year period. But mortality rates would have risen during the following seventeen years. This happens because a move to abstinence would preserve alive some part of the population. This part of the population is presumably at a higher risk of mortality than other parts because a move to abstinence makes a difference in whether this part stays alive. In later years, as the population ages and mortality rates necessarily rise, this part of the population begins to die at higher rates. This compositional effect is analogous to what we term "catch-up" mortality in Russia after the end of the Gorbachev Anti-Alcohol Campaign.

Appendix Figure 4 shows the mortality rate difference over time for Scenario 2 (which compares mortality rates in a counterfactual scenario in which there is a five-year period during which heavy drinkers become light drinkers and moderate and light drinkers abstain against observed mortality). This "campaign" changes heavy drinkers into light drinkers and moderate and light drinkers into abstainers, and all individuals then revert to their pre-campaign drinking path. Given the results from Scenario 1, it is unsurprising to see an initial reduction in mortality during the campaign followed by an increase leading to excess mortality beginning three years after the campaign's end.

Appendix Figure 5 shows the mortality rate difference over time for Scenario 3 (which compares mortality rates in a counterfactual scenario in which the "campaign" from Scenario 2 is followed by two years of excessive drinking, and then a return to the pre-campaign drinking path, against observed mortality). The results are qualitatively similar to the previous graph $-\mathrm{a}$ decline in mortality during the "campaign" followed by an increase leading to excess mortality (larger in magnitude and longer lasting than in Scenario 2) about two years after the end of the campaign.

The magnitudes, patterns, and composition of alcohol consumption in the United States and Russia differ markedly. Our simulations using Framingham Heart Study data are nevertheless informative about mortality patterns in Russia assuming alcohol consumption and mortality have an approximately linear (or even convex) relationship. More generally, our primary objective is simply to establish general temporal relationships between alcohol consumption and mortality consistent with those observed in Russia during the latter 1980s and early 1990s. 


\section{Appendix Figure 1}

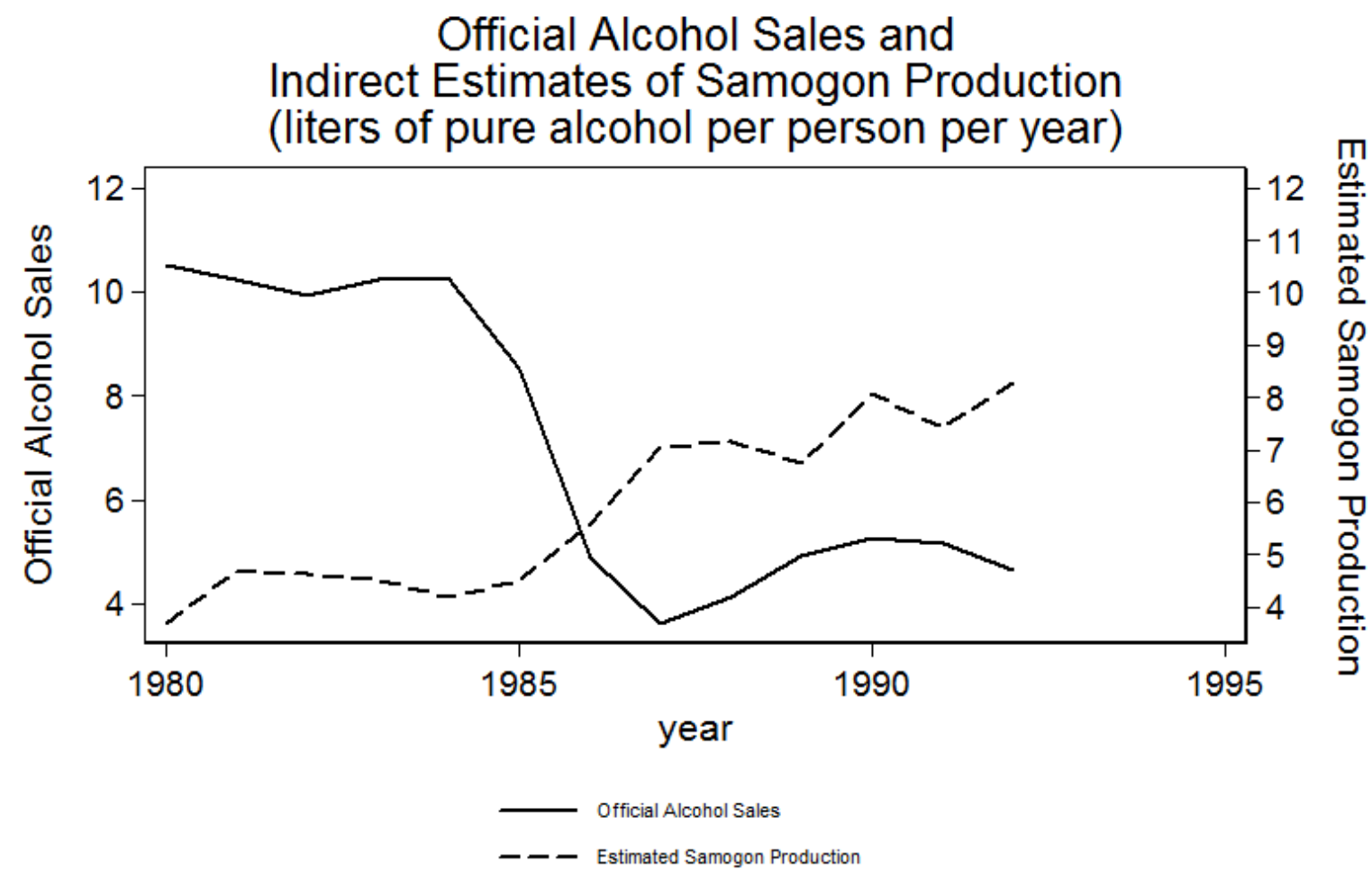

Data on official alcohol sales were obtained from annual statistical yearbooks compiled by Goskomstat and Rosstat through East View Information Services and the Hoover Institution's "Russian/Soviet/Commonwealth of Independent States Collection" print archives with supplementation from New World Demographics (1992), Treml and Alexeev (1993), Vassin and Costello (1997), Vallin et al. (2005) as well as from Vladimir Shkolnikov and colleagues at the Max Planck Institute for Demographic Research; estimates of illegal alcohol production by extending the work of Nemtsov (2000) (see Appendices 1 and 2 for details). 


\section{Appendix Figure 2}

\section{Pre-Campaign Alcohol Consumption Across Russia's Oblasts, 1985-1989}

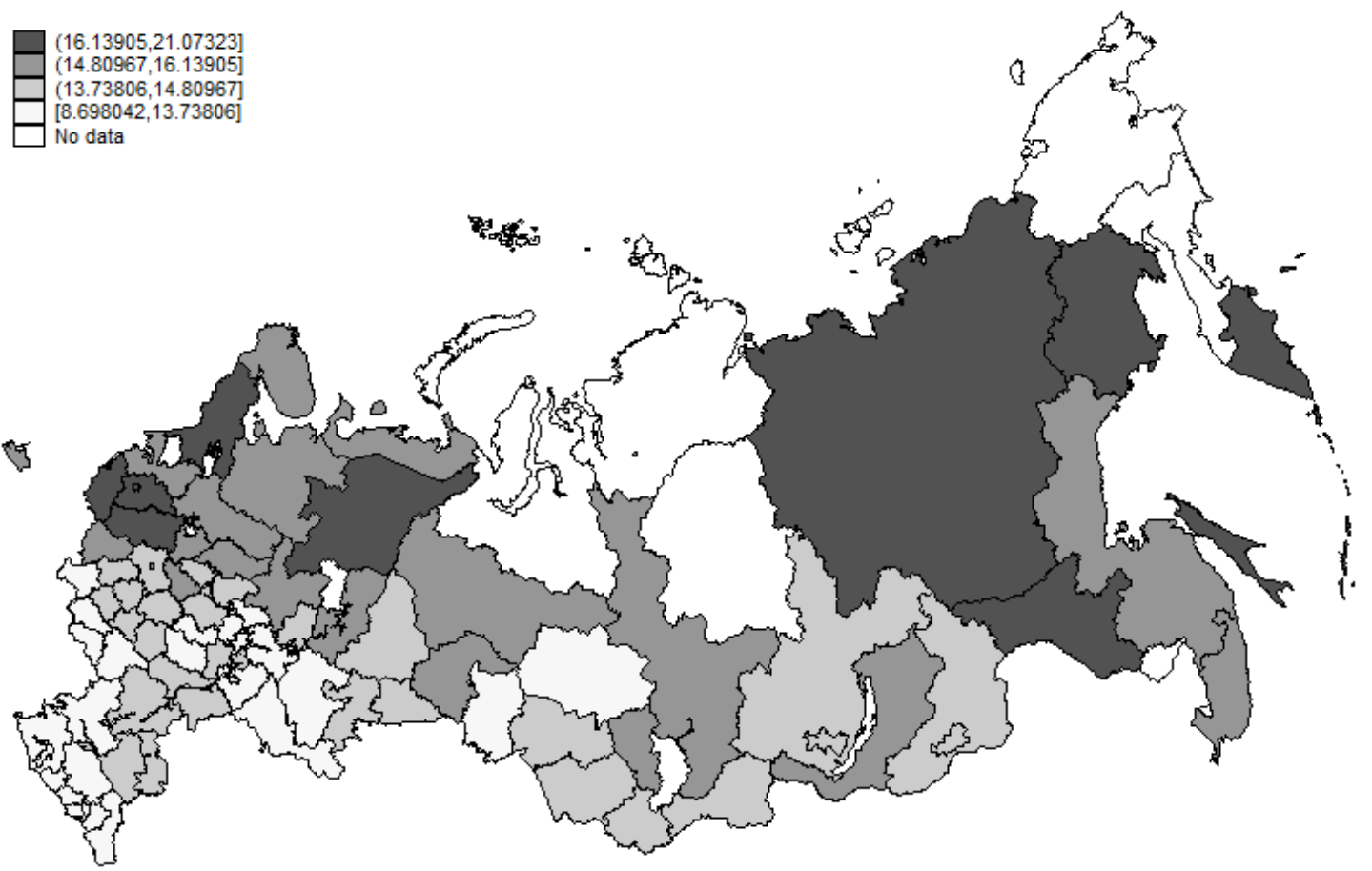

Estimates of total alcohol consumption from data on official alcohol sales and estimates of illegal alcohol production. Data on official alcohol sales are available in annual statistical yearbooks compiled by Goskomstat and Rosstat. Illegal alcohol production estimated by extending the work of Nemtsov (2000) (see Appendices 1 and 2 for details). 
Appendix Figure 3

Heavy Drinkers Become Abstainers

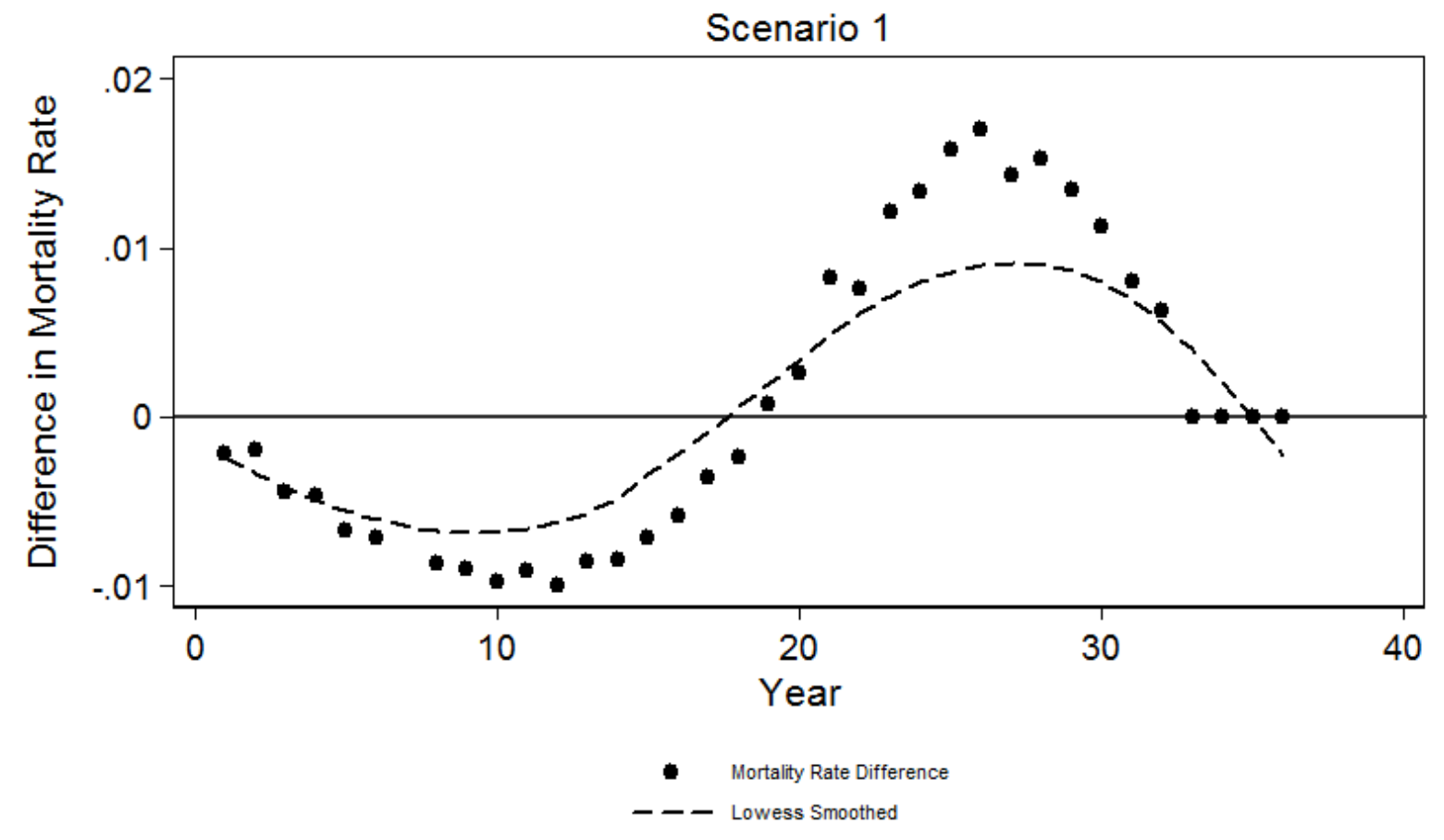


Appendix Figure 4

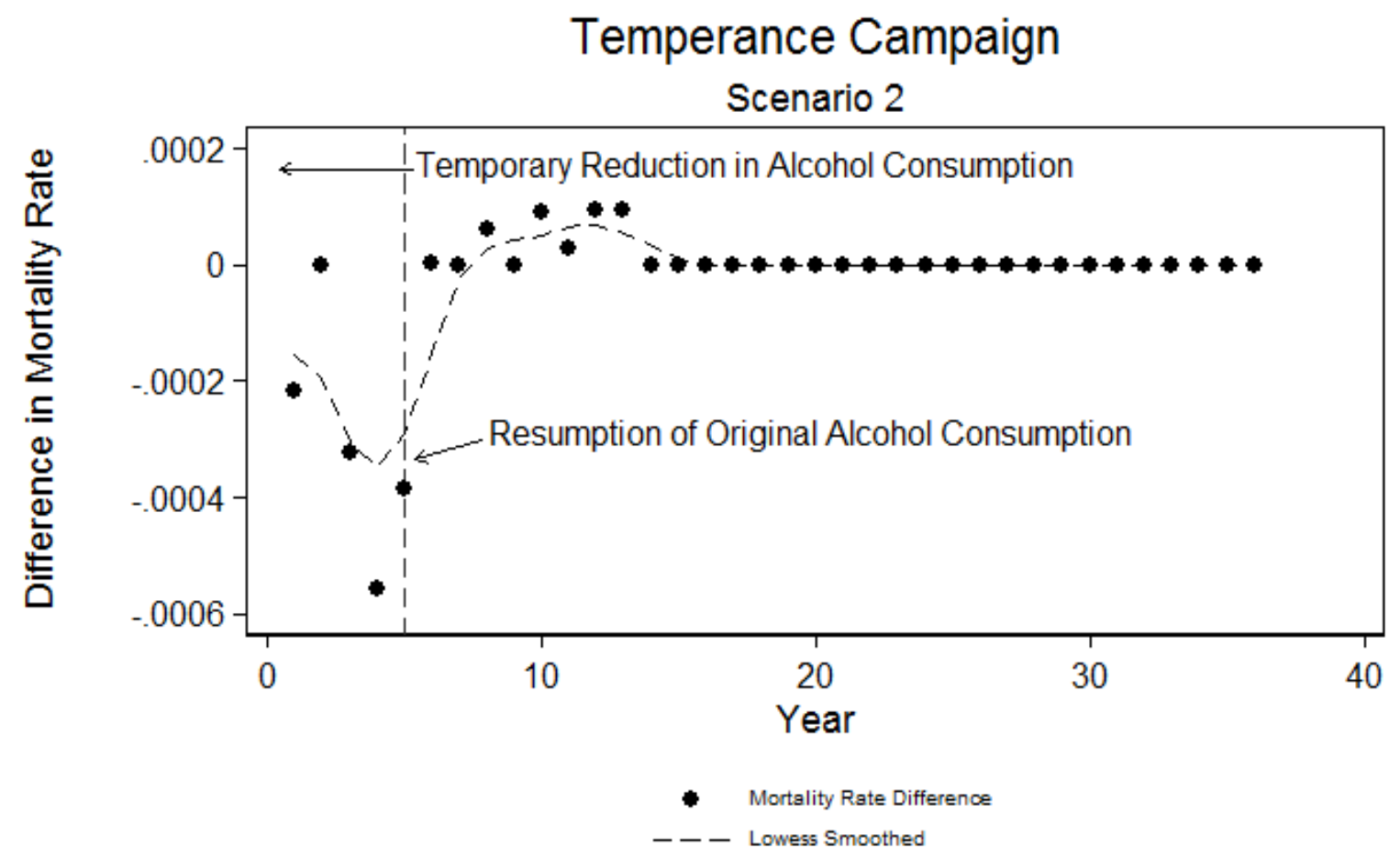

Note: $t=1$ is the first year of the 'campaign' and $t=5$ is the last year of the 'campaign' 
Appendix Figure 5

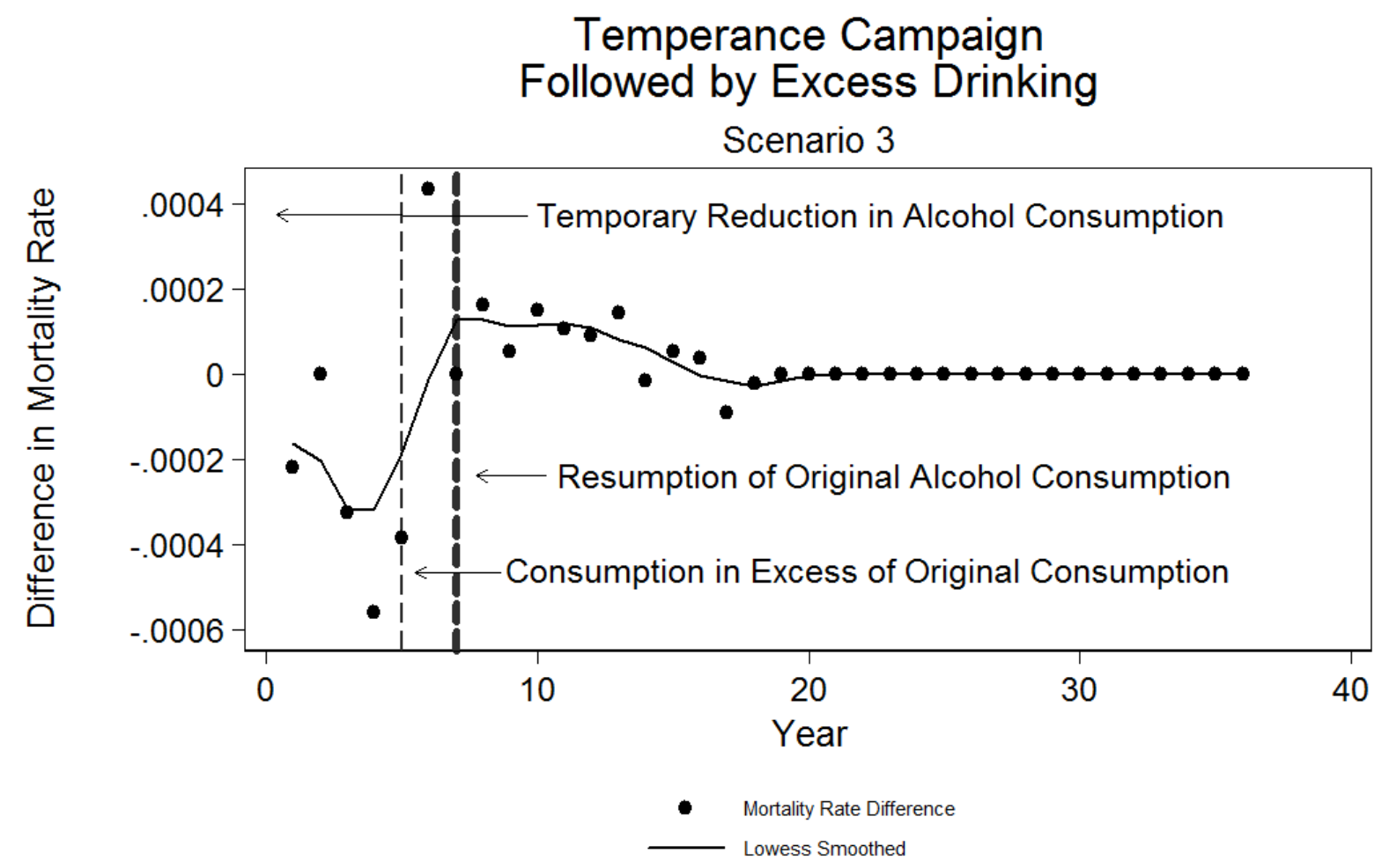


Appendix Table 1

Pre-Campaign Alcohol Consumption and Mortality With and Without Oblasts With Lower Quality Data

\begin{tabular}{|c|c|c|c|c|c|c|c|c|c|c|c|c|}
\hline \multirow{2}{*}{$\begin{array}{c}\text { Alcohol Measure: } \\
\text { Dependent Variable: } \\
\text { Campaign Year Interactions }\end{array}$} & \multicolumn{6}{|c|}{ Total Alcohol Consumption } & \multicolumn{6}{|c|}{ Official Alcohol Sales } \\
\hline & \multicolumn{6}{|c|}{ Crude Death Rate } & \multicolumn{6}{|c|}{ Crude Death Rate } \\
\hline Pre-Campaign Alcohol Consumption × 1986 & $\begin{array}{c}-0.234 * * * * \\
(0.057)\end{array}$ & $\begin{array}{c}-0.196 * * * \\
(0.065)\end{array}$ & $\begin{array}{c}-0.225 * * * * \\
(0.057)\end{array}$ & $\begin{array}{c}-0.123 * * \\
(0.061)\end{array}$ & $\begin{array}{c}-0.264 * * * * \\
(0.058)\end{array}$ & $\begin{array}{c}-0.091 * * \\
(0.038)\end{array}$ & $\begin{array}{c}-0.227 * * * \\
(0.056)\end{array}$ & $\begin{array}{c}-0.184 * * * * * \\
(0.062)\end{array}$ & $\begin{array}{c}-0.219 \text { **** } \\
(0.055)\end{array}$ & $\begin{array}{c}-0.121 * * \\
(0.059)\end{array}$ & $\begin{array}{c}-0.255 * * * \\
(0.056)\end{array}$ & $\begin{array}{c}-0.085^{* *} \\
(0.037)\end{array}$ \\
\hline Pre-Campaign Alcohol Consumption × 1989 & $\begin{array}{c}-0.278^{* * * *} \\
(0.054)\end{array}$ & $\begin{array}{c}-0.211^{* *} \\
(0.085)\end{array}$ & $\begin{array}{c}-0.292^{* * * * *} \\
(0.090)\end{array}$ & $\begin{array}{l}-0.119 \\
(0.078)\end{array}$ & $\begin{array}{c}-0.308^{* * * *} \\
(0.058)\end{array}$ & $\begin{array}{l}-0.082 \\
(0.056)\end{array}$ & $\begin{array}{c}-0.265 * * * * \\
(0.053)\end{array}$ & $\begin{array}{c}-0.194 * * \\
(0.080)\end{array}$ & $\begin{array}{c}-0.282^{* * * *} \\
(0.088)\end{array}$ & $\begin{array}{l}-0.117 \\
(0.075)\end{array}$ & $\begin{array}{c}-0.293^{* * * *} * \\
(0.055)\end{array}$ & $\begin{array}{l}-0.072 \\
(0.053)\end{array}$ \\
\hline \multicolumn{13}{|l|}{$\underline{\text { Crisis Year Interactions }}$} \\
\hline Pre-Campaign Alcohol Consumption $\times 1992$ & $\begin{array}{l}-0.034 \\
(0.065)\end{array}$ & $\begin{array}{c}0.047 \\
(0.084)\end{array}$ & $\begin{array}{l}-0.040 \\
(0.075)\end{array}$ & $\begin{array}{c}0.116 \\
(0.103)\end{array}$ & $\begin{array}{c}-0.126^{* * *} \\
(0.059)\end{array}$ & $\begin{array}{l}0.152^{*} \\
(0.083)\end{array}$ & $\begin{array}{l}-0.032 \\
(0.064)\end{array}$ & $\begin{array}{c}0.052 \\
(0.079)\end{array}$ & $\begin{array}{l}-0.039 \\
(0.073)\end{array}$ & $\begin{array}{c}0.109 \\
(0.098)\end{array}$ & $\begin{array}{c}-0.118^{* * *} \\
(0.057)\end{array}$ & $\begin{array}{l}0.151^{*} \\
(0.079)\end{array}$ \\
\hline Pre-Campaign Alcohol Consumption $\times 1993$ & $\begin{array}{c}0.131 \\
(0.099)\end{array}$ & $\begin{array}{c}0.221^{* *} \\
(0.093)\end{array}$ & $\begin{array}{c}0.123 \\
(0.110)\end{array}$ & $\begin{array}{c}0.299 * * * \\
(0.106)\end{array}$ & $\begin{array}{l}-0.001 \\
(0.087)\end{array}$ & $\begin{array}{c}0.292 * * * * \\
(0.094)\end{array}$ & $\begin{array}{c}0.125 \\
(0.095)\end{array}$ & $\begin{array}{c}0.218^{* * *} \\
(0.087)\end{array}$ & $\begin{array}{c}0.115 \\
(0.106)\end{array}$ & $\begin{array}{c}0.281^{* * * *} \\
(0.100)\end{array}$ & $\begin{array}{c}-0.000 \\
(0.083)\end{array}$ & $\begin{array}{c}0.285 * * * * \\
(0.090)\end{array}$ \\
\hline Pre-Campaign Alcohol Consumption $\times 1994$ & $\begin{array}{l}0.243^{*} \\
(0.123)\end{array}$ & $\begin{array}{c}0.340^{* * * * *} \\
(0.085)\end{array}$ & $\begin{array}{l}0.237 * \\
(0.136)\end{array}$ & $\begin{array}{c}0.425 * * * * \\
(0.093)\end{array}$ & $\begin{array}{c}0.070 \\
(0.107)\end{array}$ & $\begin{array}{c}0.379 * * * * \\
(0.082)\end{array}$ & $\begin{array}{l}0.227^{*} \\
(0.118)\end{array}$ & $\begin{array}{c}0.328 * * * \\
(0.079)\end{array}$ & $\begin{array}{l}0.220^{*} \\
(0.131)\end{array}$ & $\begin{array}{c}0.397 * * * \\
(0.087)\end{array}$ & $\begin{array}{c}0.061 \\
(0.102)\end{array}$ & $\begin{array}{c}0.362 * * * * \\
(0.078)\end{array}$ \\
\hline Pre-Campaign Alcohol Consumption × 1995 & $\begin{array}{c}0.324 * * * * \\
(0.118)\end{array}$ & $\begin{array}{c}0.407 \text { ***** } \\
(0.107)\end{array}$ & $\begin{array}{c}0.306 * * \\
(0.124)\end{array}$ & $\begin{array}{c}0.496^{* * * *} \\
(0.100)\end{array}$ & $\begin{array}{c}0.192 \\
(0.137)\end{array}$ & $\begin{array}{c}0.517 * * * * \\
(0.088)\end{array}$ & $\begin{array}{c}0.306^{* * * *} \\
(0.113)\end{array}$ & $\begin{array}{c}0.394 * * * \\
(0.100)\end{array}$ & $\begin{array}{c}0.287^{* * *} \\
(0.119)\end{array}$ & $\begin{array}{c}0.466 * * * * \\
(0.097)\end{array}$ & $\begin{array}{c}0.180 \\
(0.131)\end{array}$ & $\begin{array}{c}0.497 * * * * \\
(0.084)\end{array}$ \\
\hline Pre-Campaign Alcohol Consumption × 1996 & $\begin{array}{l}0.159^{*} \\
(0.087)\end{array}$ & $\begin{array}{c}0.245^{* * *} \\
(0.103)\end{array}$ & $\begin{array}{c}0.141 \\
(0.093)\end{array}$ & $\begin{array}{c}0.332 * * * * \\
(0.117)\end{array}$ & $\begin{array}{c}0.032 \\
(0.075)\end{array}$ & $\begin{array}{c}0.373 * * * * \\
(0.085)\end{array}$ & $\begin{array}{l}0.145^{*} \\
(0.084)\end{array}$ & $\begin{array}{l}0.236 * * \\
(0.096)\end{array}$ & $\begin{array}{c}0.126 \\
(0.091)\end{array}$ & $\begin{array}{c}0.307^{* * * * *} \\
(0.112)\end{array}$ & $\begin{array}{c}0.022 \\
(0.072)\end{array}$ & $\begin{array}{c}0.355 * * * * \\
(0.081)\end{array}$ \\
\hline Pre-Campaign Alcohol Consumption $\times 2000$ & $\begin{array}{c}0.156 \\
(0.155)\end{array}$ & $\begin{array}{l}0.252^{*} \\
(0.131)\end{array}$ & $\begin{array}{c}0.148 \\
(0.162)\end{array}$ & $\begin{array}{c}0.344 * * \\
(0.134)\end{array}$ & $\begin{array}{l}-0.103 \\
(0.095)\end{array}$ & $\begin{array}{c}0.303 * * * \\
(0.109)\end{array}$ & $\begin{array}{c}0.138 \\
(0.151)\end{array}$ & $\begin{array}{l}0.241 * \\
(0.123)\end{array}$ & $\begin{array}{c}0.125 \\
(0.156)\end{array}$ & $\begin{array}{c}0.311^{* *} \\
(0.128)\end{array}$ & $\begin{array}{l}-0.120 \\
(0.090)\end{array}$ & $\begin{array}{c}0.277 * * * \\
(0.104)\end{array}$ \\
\hline \multicolumn{13}{|l|}{ Additional Controls } \\
\hline Per capita number of doctors & & & $\begin{array}{l}-0.006 \\
(0.013)\end{array}$ & $\begin{array}{c}0.006 \\
(0.010)\end{array}$ & & & & & $\begin{array}{l}-0.006 \\
(0.013)\end{array}$ & $\begin{array}{c}0.005 \\
(0.009)\end{array}$ & & \\
\hline Per capita number of hospital beds & & & $\begin{array}{c}0.014 \\
(0.073)\end{array}$ & $\begin{array}{l}-0.042 \\
(0.036)\end{array}$ & & & & & $\begin{array}{c}0.012 \\
(0.074)\end{array}$ & $\begin{array}{l}-0.043 \\
(0.036)\end{array}$ & & \\
\hline Oblasts with Lower-Quality Data & Yes & Yes & Yes & Yes & No & No & Yes & Yes & Yes & Yes & No & No \\
\hline Additional Controls & No & No & Yes & Yes & No & No & No & No & Yes & Yes & No & No \\
\hline Year Fixed Effects & Yes & Yes & Yes & Yes & Yes & Yes & Yes & Yes & Yes & Yes & Yes & Yes \\
\hline Oblast Fixed Effects & Yes & Yes & Yes & Yes & Yes & Yes & Yes & Yes & Yes & Yes & Yes & Yes \\
\hline Oblast-Specific Time Trends & No & Yes & No & Yes & No & Yes & No & Yes & No & Yes & No & Yes \\
\hline $\mathrm{N}$ & 1,371 & & 1,293 & 1,293 & 1,237 & 1,237 & 1,371 & 1,371 & 1,293 & 1,293 & 1,237 & 1,237 \\
\hline $\mathrm{R}^{2}$ & 0.947 & & 0.952 & 0.977 & 0.952 & 0.976 & 0.947 & 0.974 & 0.951 & 0.977 & 0.952 & 0.976 \\
\hline
\end{tabular}

Data on death rates and official alcohol sales were obtained from annual statistical yearbooks compiled by Goskomstat and Rosstat through East View Information Services and the Hoover Institution's “Russian/Soviet/Commonwealth of Independent States Collection” print archives with supplementation from New World Demographics (1992), Treml and Alexeev (1993), Vassin and Costello (1997), Vallin et al. (2005) as well as from Vladimir Shkolnikov and colleagues at the Max Planck Institute for Demographic Research; estimates of total alcohol consumption by extending the work of Nemtsov (2000) for estimating illegal alcohol production (see Appendices 1 and 2 for details). Data sources for additional control variables available in Appendix 1. Table cells report OLS estimates obtained from equation (1) for interactions between oblast-level mean pre-campaign alcohol consumption and campaign year dummy variables. All specifications cells report OLS estimates obtained from equation (1) for interactions between oblast-level mean pre-campaign alcohol consumption and campaign year dummy variables. All specifications
include oblast and year fixed effects. Crude death rates are per 1,000 population. All oblast-year samples are restricted to years prior to 2000 (1970, 1978, 1980, 1985, 1986, 1988, and include oblast and year fixed effects. Crude death rates are per 1,000 population. All oblast-year samples are restricted to years prior to 2000 (1970, 1978, 1980, 1985, 1986, 1988, and
1989-2000) and exclude Tuva, Dagastan Republic, Ingushitya Republic, Chechen Republic, Kabardino-Balkarskaya Republic, Karachaevo-Cherkesskaya Republic, North Osetiya-Alaniya Republic, Krasnodarskiy Krai, and Stavropolski Krai. Standard errors clustered at the oblast level shown in parentheses. *p $<0.10$, ** $<<0.05$, and $* * * p<0.01$. 
Appendix Table 2

Pre-Campaign Alcohol Consumption and Cause-Specific Mortality

\begin{tabular}{|c|c|c|c|c|c|c|c|c|}
\hline \multirow{2}{*}{$\begin{array}{c}\text { Alcohol Measure: } \\
\text { Dependent Variable: }\end{array}$} & \multicolumn{8}{|c|}{ Total Alcohol Consumption } \\
\hline & $\begin{array}{c}\text { Alcohol } \\
\text { Poisoning Death } \\
\text { Rate (Total) }\end{array}$ & $\begin{array}{c}\text { Alcohol } \\
\text { Poisoning Death } \\
\text { Rate (Male) }\end{array}$ & $\begin{array}{c}\text { Alcohol } \\
\text { Poisoning Death } \\
\text { Rate (Female) }\end{array}$ & $\begin{array}{c}\text { Circulatory } \\
\text { Disease Death } \\
\text { Rate }\end{array}$ & $\begin{array}{c}\text { Accident or } \\
\text { Violent Death } \\
\text { Rate }\end{array}$ & $\begin{array}{c}\text { Respiratory } \\
\text { Disease } \\
\text { Death Rate }\end{array}$ & $\begin{array}{l}\text { Digestive } \\
\text { Disease } \\
\text { Death Rate }\end{array}$ & $\begin{array}{c}\text { Cancer } \\
\text { Death Rate }\end{array}$ \\
\hline Pre-Campaign Alcohol Consumption $\times 1988$ & $\begin{array}{c}-4.907 * * * \\
(0.870)\end{array}$ & $\begin{array}{c}-7.067 \text { **** } \\
(1.124)\end{array}$ & $\begin{array}{c}-2.747 * * * \\
(0.669)\end{array}$ & $\begin{array}{l}-3.312 \\
(5.512)\end{array}$ & $\begin{array}{c}-9.521 \text { *** } \\
(1.533)\end{array}$ & $\begin{array}{l}-1.686 \\
(1.656)\end{array}$ & $\begin{array}{l}-0.952 \\
(0.611)\end{array}$ & $\begin{array}{l}-0.475 \\
(1.146)\end{array}$ \\
\hline Pre-Campaign Alcohol Consumption $\times 1989$ & $\begin{array}{c}-4.295 * * * \\
(1.000)\end{array}$ & $\begin{array}{c}-6.078^{* * * *} \\
(1.380)\end{array}$ & $\begin{array}{c}-2.511 * * * \\
(0.697)\end{array}$ & & & & & \\
\hline \multicolumn{9}{|l|}{$\underline{\text { Crisis Year Interactions }}$} \\
\hline Pre-Campaign Alcohol Consumption $\times 1990$ & $\begin{array}{c}-3.913 * * * \\
(0.830)\end{array}$ & $\begin{array}{c}-5.450^{* * * *} \\
(1.112)\end{array}$ & $\begin{array}{c}-2.376^{* * *} \\
(0.641)\end{array}$ & $\begin{array}{l}-4.638 \\
(3.447)\end{array}$ & $\begin{array}{c}-6.791 \text { **** } \\
(1.315)\end{array}$ & $\begin{array}{c}0.791 \\
(1.511)\end{array}$ & $\begin{array}{l}-0.0816 \\
(0.512)\end{array}$ & $\begin{array}{l}-0.357 \\
(0.760)\end{array}$ \\
\hline Pre-Campaign Alcohol Consumption $\times 1991$ & $\begin{array}{c}-3.603 * * * \\
(1.174)\end{array}$ & $\begin{array}{c}-5.168^{* * * *} \\
(1.704)\end{array}$ & $\begin{array}{c}-2.039 * * * \\
(0.713)\end{array}$ & $\begin{array}{l}-4.532 \\
(3.331)\end{array}$ & $\begin{array}{c}-6.053^{* * * *} \\
(1.560)\end{array}$ & $\begin{array}{c}1.326 \\
(1.682)\end{array}$ & $\begin{array}{l}-0.389 \\
(0.561)\end{array}$ & $\begin{array}{l}-0.102 \\
(1.012)\end{array}$ \\
\hline Pre-Campaign Alcohol Consumption $\times 1992$ & $\begin{array}{c}-1.839^{* *} * \\
(0.917)\end{array}$ & $\begin{array}{c}-2.349^{*} \\
(1.271)\end{array}$ & $\begin{array}{c}-1.328 * * \\
(0.628)\end{array}$ & $\begin{array}{c}1.951 \\
(3.139)\end{array}$ & $\begin{array}{l}-0.213 \\
(1.808)\end{array}$ & $\begin{array}{c}1.797 \\
(1.681)\end{array}$ & $\begin{array}{l}-0.101 \\
(0.705)\end{array}$ & $\begin{array}{c}0.162 \\
(1.272)\end{array}$ \\
\hline Pre-Campaign Alcohol Consumption $\times 1993$ & $\begin{array}{c}2.501^{* * * *} \\
(0.873)\end{array}$ & $\begin{array}{c}5.143 * * * \\
(1.309)\end{array}$ & $\begin{array}{l}-0.140 \\
(0.838)\end{array}$ & $\begin{array}{l}11.46^{* * *} \\
(5.494)\end{array}$ & $\begin{array}{c}9.308^{* * * *} \\
(2.602)\end{array}$ & $\begin{array}{c}3.217^{* * *} \\
(1.394)\end{array}$ & $\begin{array}{l}1.275^{*} \\
(0.699)\end{array}$ & $\begin{array}{c}0.926 \\
(1.405)\end{array}$ \\
\hline Pre-Campaign Alcohol Consumption $\times 1994$ & $\begin{array}{c}2.472 \\
(1.581)\end{array}$ & $\begin{array}{l}4.624^{*} \\
(2.382)\end{array}$ & $\begin{array}{c}0.321 \\
(0.979)\end{array}$ & $\begin{array}{c}17.03 * * \\
(7.108)\end{array}$ & $\begin{array}{c}11.28 * * * \\
(3.074)\end{array}$ & $\begin{array}{c}4.759 * * * \\
(1.423)\end{array}$ & $\begin{array}{c}1.340^{* * *} \\
(0.614)\end{array}$ & $\begin{array}{c}1.653 \\
(1.392)\end{array}$ \\
\hline Pre-Campaign Alcohol Consumption $\times 1995$ & $\begin{array}{l}0.0440 \\
(1.117)\end{array}$ & $\begin{array}{c}0.714 \\
(1.472)\end{array}$ & $\begin{array}{l}-0.626 \\
(0.826)\end{array}$ & $\begin{array}{c}19.70^{* * * *} \\
(6.007)\end{array}$ & $\begin{array}{l}15.03 * * \\
(6.624)\end{array}$ & $\begin{array}{c}4.948^{* * *} \\
(1.321)\end{array}$ & $\begin{array}{l}1.231 * * \\
(0.609)\end{array}$ & $\begin{array}{c}1.841 \\
(1.782)\end{array}$ \\
\hline Pre-Campaign Alcohol Consumption $\times 1996$ & $\begin{array}{l}-2.028 \\
(1.244)\end{array}$ & $\begin{array}{l}-2.699 \\
(1.670)\end{array}$ & $\begin{array}{l}-1.356 \\
(0.850)\end{array}$ & $\begin{array}{l}15.12 * * \\
(5.909)\end{array}$ & $\begin{array}{c}4.196 * * \\
(1.598)\end{array}$ & $\begin{array}{c}4.236^{* * * *} \\
(1.122)\end{array}$ & $\begin{array}{l}1.534^{* * *} \\
(0.606)\end{array}$ & $\begin{array}{c}1.792 \\
(1.658)\end{array}$ \\
\hline Pre-Campaign Alcohol Consumption $\times 1997$ & $\begin{array}{c}-2.988^{* * *} \\
(1.160)\end{array}$ & $\begin{array}{c}-4.166^{* * * *} \\
(1.522)\end{array}$ & $\begin{array}{c}-1.809 * * \\
(0.825)\end{array}$ & $\begin{array}{c}8.759 \\
(6.231)\end{array}$ & $\begin{array}{c}1.745 \\
(1.630)\end{array}$ & $\begin{array}{c}3.126 * * * \\
(1.159)\end{array}$ & $\begin{array}{c}0.831 \\
(0.579)\end{array}$ & $\begin{array}{c}1.233 \\
(1.477)\end{array}$ \\
\hline Pre-Campaign Alcohol Consumption $\times 1998$ & $\begin{array}{c}-3.174 * * \\
(1.271)\end{array}$ & $\begin{array}{c}-4.378 * * \\
(1.695)\end{array}$ & $\begin{array}{c}-1.969 * * \\
(0.900)\end{array}$ & $\begin{array}{c}9.894 \\
(6.250)\end{array}$ & $\begin{array}{c}0.283 \\
(1.802)\end{array}$ & $\begin{array}{c}3.177 * * \\
(1.243)\end{array}$ & $\begin{array}{c}0.889 \\
(0.647)\end{array}$ & $\begin{array}{c}1.569 \\
(1.595)\end{array}$ \\
\hline Pre-Campaign Alcohol Consumption $\times 1999$ & $\begin{array}{c}-3.098^{* *} * \\
(1.430)\end{array}$ & $\begin{array}{c}-4.370 * * \\
(1.968)\end{array}$ & $\begin{array}{c}-1.827 * \\
(0.938)\end{array}$ & $\begin{array}{l}15.11^{*} \\
(8.685)\end{array}$ & $\begin{array}{c}1.485 \\
(2.516)\end{array}$ & $\begin{array}{c}3.846^{* * * *} \\
(1.190)\end{array}$ & $\begin{array}{c}1.765^{* * *} \\
(0.735)\end{array}$ & $\begin{array}{c}2.510 \\
(1.905)\end{array}$ \\
\hline Pre-Campaign Alcohol Consumption $\times 2000$ & $\begin{array}{l}-1.464 \\
(1.542)\end{array}$ & $\begin{array}{l}-1.826 \\
(2.142)\end{array}$ & $\begin{array}{l}-1.102 \\
(0.976)\end{array}$ & $\begin{array}{c}14.17 \\
(9.506)\end{array}$ & $\begin{array}{c}3.775 \\
(3.719)\end{array}$ & $\begin{array}{c}4.576^{* * * *} \\
(1.315)\end{array}$ & $\begin{array}{l}1.446^{*} \\
(0.853)\end{array}$ & $\begin{array}{c}2.597 \\
(1.937)\end{array}$ \\
\hline Year Fixed Effects & Yes & Yes & Yes & Yes & Yes & Yes & Yes & Yes \\
\hline Oblast Fixed Effects & Yes & Yes & Yes & Yes & Yes & Yes & Yes & Yes \\
\hline Oblast-Specific Time Trends & No & No & No & No & No & No & No & No \\
\hline $\mathrm{N}$ & 1,062 & 1,062 & 1,062 & 1,016 & 1,016 & 1,016 & 1,016 & 1,016 \\
\hline $\mathrm{R}^{2}$ & 0.795 & 0.802 & 0.750 & 0.951 & 0.901 & 0.816 & 0.728 & 0.961 \\
\hline
\end{tabular}

Data on death rates and official alcohol sales were obtained from annual statistical yearbooks compiled by Goskomstat and Rosstat through East View Information Services and the Hoover Institution's "Russian/Soviet/Commonwealth of Independent States Collection" print archives with supplementation from New World Demographics (1992), Treml and Alexeev (1993), Vassin and Costello (1997), Vallin et al. (2005) as well as from Vladimir Shkolnikov and colleagues at the Max Planck Institute for Demographic Research; estimates of total alcohol consumption by extending the work of

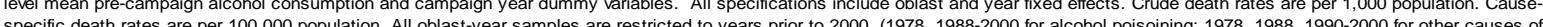
death) and exclude Tur , Krasnodarskiy Krai, and Stavropolski Krai. Standard errors clustered at the oblast level shown in parentheses. ${ }^{*} \mathrm{p}<0.10$, ${ }^{* *} \mathrm{p}<0.05$, and ${ }^{* * *} \mathrm{p}<0.01$. 
Appendix Table 3

Implied Changes in Crude Death Rate: High and Low Drinking Oblasts

\begin{tabular}{|c|c|c|c|c|c|c|c|c|}
\hline \multirow[b]{2}{*}{ Year } & \multirow[b]{2}{*}{ Estimate of $\boldsymbol{\beta}$} & \multicolumn{4}{|c|}{ Pre-Campaign Median Consumption } & \multicolumn{3}{|c|}{ Implied Change in Mortality } \\
\hline & & Median & $\begin{array}{l}\text { Standard- } \\
\text { Deviation }\end{array}$ & $\begin{array}{c}1 \text { Standard } \\
\text { Deviation } \\
\text { Below Median }\end{array}$ & $\begin{array}{c}1 \text { Standard } \\
\text { Deviation } \\
\text { Above Median }\end{array}$ & $\begin{array}{c}\text { Standard } \\
\text { Deviation } \\
\text { Below Median }\end{array}$ & Median & $\begin{array}{c}1 \text { Standard } \\
\text { Deviation } \\
\text { Above Median }\end{array}$ \\
\hline 1985 & -0.14 & 14.38 & 2.00 & 12.38 & 16.38 & -1.78 & -2.07 & -2.36 \\
\hline 1986 & -0.20 & 14.38 & 1.96 & 12.42 & 16.34 & -2.43 & -2.82 & -3.20 \\
\hline 1989 & -0.21 & 14.38 & 1.93 & 12.45 & 16.31 & -2.63 & -3.03 & -3.44 \\
\hline 1990 & -0.14 & 14.38 & 2.00 & 12.38 & 16.38 & -1.78 & -2.07 & -2.36 \\
\hline 1991 & -0.09 & 14.38 & 1.94 & 12.44 & 16.32 & -1.15 & -1.33 & -1.51 \\
\hline 1992 & 0.05 & 14.38 & 1.91 & 12.47 & 16.29 & 0.59 & 0.68 & 0.77 \\
\hline 1993 & 0.22 & 14.38 & 1.80 & 12.58 & 16.18 & 2.78 & 3.18 & 3.58 \\
\hline 1994 & 0.34 & 14.38 & 1.80 & 12.58 & 16.18 & 4.28 & 4.89 & 5.50 \\
\hline 1995 & 0.41 & 14.38 & 1.90 & 12.48 & 16.28 & 5.08 & 5.85 & 6.63 \\
\hline 1996 & 0.25 & 14.38 & 1.90 & 12.48 & 16.28 & 3.06 & 3.52 & 3.99 \\
\hline 1997 & 0.12 & 14.38 & 1.90 & 12.48 & 16.28 & 1.45 & 1.67 & 1.89 \\
\hline 1999 & 0.22 & 14.38 & 1.99 & 12.39 & 16.37 & 2.75 & 3.19 & 3.63 \\
\hline 2000 & 0.25 & 14.38 & 1.99 & 12.39 & 16.37 & 3.12 & 3.62 & 4.13 \\
\hline
\end{tabular}

Data on death rates and official alcohol sales were obtained from annual statistical yearbooks compiled by Goskomstat and Rosstat through East View Information Services and the Hoover Institution's "Russian/Soviet/Commonwealth of Independent States Collection" print archives with supplementation from New World Demographics (1992), Treml and Alexeev (1993), Vassin and Costello (1997), Vallin et al. (2005) as well as from Vladimir Shkolnikov and colleagues at the Max Planck Institute for Demographic Research; estimates of total alcohol consumption by extending the work of Nemtsov (2000) for estimating illegal alcohol production (see Appendices 1 and 2 for details). Estimated coefficients for each year obtained through OLS estimation of equation (1) for interactions between oblast-level mean precampaign alcohol consumption and campaign year dummy variables. All specifications include oblast and year fixed effects. Alcohol consumption is measured in liters per capita. Changes in mortality reflect the number deaths averted (or excess deaths) per 1,000 population. All oblast-year samples are restricted to years prior to 2000 (1970, 1978, 1980, 1985, 1986, and 1988-2000) and exclude Tuva, Dagastan Republic, Ingushitya Republic, Chechen Republic, Kabardino-Balkarskaya Republic, Karachaevo-Cherkess kaya Republic, North Osetiya-Alaniya Republic, Krasnodarskiy Krai, and Stavropolski Krai. Standard errors clustered at the oblast level shown in parentheses. ${ }^{*} \mathrm{p}<0.10, * * \mathrm{p}<0.05$, and $* * * \mathrm{p}<0.01$. 
Appendix Table 4

Comparison of Total Alcohol Consumption Estimates

(Including Samogon) with Nemtsov (2000)

\begin{tabular}{lcccc}
\hline \hline & \multicolumn{2}{c}{$\begin{array}{r}\text { 1984 Total Alcohol } \\
\text { Consumption }\end{array}$} & \multicolumn{2}{c}{$\begin{array}{c}1990 \text { Total Alcohol } \\
\text { Consumption }\end{array}$} \\
\hline \multicolumn{1}{c}{ Year: } & Estimate & $\begin{array}{c}\text { Nemtsov } \\
(2000)\end{array}$ & Estimate & $\begin{array}{c}\text { Nemtsov } \\
(2000)\end{array}$ \\
\hline \multicolumn{1}{c}{ Region: } & & & & \\
North and Northwest & 16.0 & 15.6 & 12.5 & 12.3 \\
Central & 14.3 & 14.6 & 12.4 & 12.2 \\
Northern Caucasus & 13.0 & 12.7 & 11.0 & 10.7 \\
Urals and Volga country & 14.0 & 13.9 & 11.8 & 11.4 \\
Western Siberia & 14.8 & 14.8 & 13.4 & 12.8 \\
Russian Far East & 17.2 & 16.7 & 13.5 & 13.3 \\
& & & & \\
\hline \hline
\end{tabular}

Data on official alcohol sales were obtained from annual statistical yearbooks compiled by Goskomstat and Rosstat through East View Information Services and the Hoover Institution's 'Russian/Soviet/Commonwealth of Independent States Collection” print archives with supplementation from New World Demographics (1992); estimates of total alcohol consumption by extending the work of Nemtsov (2000) for estimating illegal alcohol production (see Appendices 1 and 2 for details). 
Appendix Table 5:

An Aging Framingham Population

\begin{tabular}{|c|c|c|c|c|c|c|c|c|}
\hline \multirow[b]{2}{*}{ Variable } & \multicolumn{2}{|c|}{ Wave 1} & \multicolumn{2}{|c|}{ Wave 7} & \multicolumn{2}{|c|}{ Wave 17} & \multicolumn{2}{|c|}{ Wave 23} \\
\hline & Mean & St. Dev. & Mean & St. Dev. & Mean & St. Dev. & Mean & St. Dev. \\
\hline \multicolumn{9}{|l|}{ Alcohol Consumption } \\
\hline none & . & . & 0.41 & 0.49 & 0.45 & 0.5 & 0.61 & 0.49 \\
\hline light & . & . & 0.14 & 0.35 & 0.14 & 0.34 & 0.14 & 0.35 \\
\hline moderate & . & 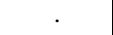 & 0.28 & 0.45 & 0.28 & 0.45 & 0.19 & 0.39 \\
\hline heavy & & & 0.17 & 0.38 & 0.13 & 0.34 & 0.07 & 0.25 \\
\hline \multicolumn{9}{|l|}{ Education } \\
\hline 8 th grade or less & 0.29 & 0.45 & 0.28 & 0.45 & 0.24 & 0.42 & 0.2 & 0.4 \\
\hline some high school & 0.14 & 0.35 & 0.14 & 0.35 & 0.14 & 0.34 & 0.13 & 0.33 \\
\hline high school graduate & 0.29 & 0.46 & 0.3 & 0.46 & 0.32 & 0.47 & 0.35 & 0.48 \\
\hline some college & 0.08 & 0.27 & 0.08 & 0.27 & 0.09 & 0.28 & 0.09 & 0.28 \\
\hline college graduate & 0.08 & 0.27 & 0.08 & 0.27 & 0.09 & 0.28 & 0.08 & 0.27 \\
\hline post-graduate & 0.12 & 0.33 & 0.13 & 0.33 & 0.14 & 0.35 & 0.16 & 0.37 \\
\hline male & 0.45 & 0.5 & 0.44 & 0.5 & 0.38 & 0.49 & 0.34 & 0.47 \\
\hline age & 44.52 & 8.57 & 56.14 & 8.46 & 73.59 & 7.46 & 82.5 & 5.71 \\
\hline $\mathrm{N}$ & \multicolumn{2}{|c|}{5,209} & \multicolumn{2}{|c|}{4,851} & \multicolumn{2}{|c|}{3,113} & \multicolumn{2}{|c|}{1,602} \\
\hline
\end{tabular}


Appendix Table 6

Mortality Hazard Ratios- Cox Proportional Hazards Model

\begin{tabular}{c|ccc} 
Variable & Hazard Ratio & $\begin{array}{c}\text { Robust Standard } \\
\text { Error }\end{array}$ & $\begin{array}{c}\text { 95\% Confidence } \\
\text { Interval }\end{array}$ \\
\hline $\begin{array}{c}\text { Alcohol Consumption } \\
\text { none }\end{array}$ & Reference Group & & \\
light & 0.92 & -0.049 & {$[0.83-1.03]$} \\
moderate & 0.96 & -0.039 & {$[0.88-1.04]$} \\
heavy & 1.11 & -0.059 & {$[1.00-1.23]$}
\end{tabular}

Education

8th grade or less

some high school

high school graduate

some college

college graduate

Reference Group

post-graduate

\begin{tabular}{l|lll} 
post-graduate & 0.84 & -0.047 & {$[0.75-0.93]$} \\
\hline male & 1.52 & -0.054 & {$[1.42-1.63]$} \\
\hline age & 1.08 & -0.003 & {$[1.08-1.09]$} \\
\hline
\end{tabular}

$\log \mathrm{L}=-23796.28$

Data from the Framingham Heart Study (sample construction described in Appendix 3). Hazard estimates obtained by estimating (1) in Appendix 3 


\section{Appendix Table 7}

Two Counterfactual Paths

\begin{tabular}{|c|c|c|}
\hline & $j=3$ & $j=4$ \\
\hline$t \leq 5$ & $\begin{array}{l}\text { - If } \text { none }_{i t}=1, \text { light }_{i t}=1 \text { or } \\
\text { moderate }_{i t}=1 \text {, set } \widehat{\operatorname{none}}_{i t}^{3}=1 \\
\text { - If heavy } \\
\text { - } \text { het }=1 \text {, set } \widehat{l i g h t}_{i t}^{3}=1\end{array}$ & $\begin{array}{l}\text { - If } \text { none }_{i t}=1, \text { light }_{i t}=1 \text { or } \\
\text { moderate }_{i t}=1 \text {, set } \widehat{\operatorname{none}}_{i t}^{4}=1 \\
\text { - If heavy } \text { heat }_{i t}=1 \text {, set } \widehat{l i g h t}_{i t}^{4}=1\end{array}$ \\
\hline $5<t \leq 7$ & - Set $\widehat{a l c} c_{i t}^{3}=a l c_{i t}$ & $\begin{array}{l}\text { - If } \text { none }_{i t}=1 \text {, set }{ }_{\text {light }}^{4}=1 \\
\text { - If } \text { light }_{i t}=1 \text {, set moderate } \\
\text { - If } \text { moderate }_{i t}=1 \text {, set heavy }\end{array}$ \\
\hline$t>7$ & - Set $\widehat{a l c}_{i t}^{3}=a l c_{i t}$ & - Set $\widehat{a l c}_{i t}^{4}=a l c_{i t}$ \\
\hline
\end{tabular}

